\title{
Accessibility Constraints of Patronage of Tourist Sites in Ondo and Ekiti
}

\author{
States, Nigeria
}

*Omisore, E.O. and Akande, C.G.

\begin{abstract}
The problem of inadequate accessibility to social facilities in developing countries is a serious concern, because of its negative impact on the economic potential derivable from these facilities. Of particularly interest is the accessibility constraint to tourist sites in Nigeria which has been identified to limit the economic potentials of these sites as catalyst of economic development. Hence, this paper examined the extent to which tourist sites in the study area are accessible.

32 tourist sites were identified in the study area out of which 12 were selected as sample size due to their prominence and recognition by the state governments. Purposive incidental sampling was employed in which a total of 358 respondents were interviewed in all the selected 12 tourist sites. The collected data were analyzed using frequency distribution and Likert scale.

Findings from the study showed that accessibility plays a very crucial role in the patronage of tourist sites in the study area (61.9\%). While accessibility constraint factors identified by respondents include physical distance (80.2\%) and costs (69.6\%). The study concluded that for the tourist sites to attract patronage and to realize the economic benefit from them, such sites should be made more accessible through the provision of good roads and other infrastructural facilities on the sites.

Keywords: Accessibility, Patronage, Tourist Sites, Infrastructural facilities
\end{abstract}

\section{Introduction}

Tourist sites are places of areas or places containing properties and monuments commemorating diverse sociocultural events. Such sites provide insight into how past generations lived, worked and worshiped. In developing countries, these sites are confronted with a number of problems which include abandonment, neglect, lack of maintenance and inadequate accessibility.

Accessibility is the ease with which an activity or a service can be reached or used (Social Exclusion Unit, 2003). It follows then that, in terms of tourist sites, accessibility is the ease with which they can be reached. Adequate accessibility to different sites will generate interaction among various locations. However, due to the difficulties of easy access to basic social facilities like tourist sites, it is necessary to investigate the operative and motivational factors that encourage movements to certain destinations. In both towns and cities, the problem of inadequate accessibility becomes particularly serious especially in the Nigerian context where residents do not have the ability to reach places or things that are important to them.

As a human activity, tourism deals with the movement of people in search of holiday or business. It is a driver of economy at the local, national and international levels. It is a rapidly growing phenomenon and has become one of the largest industries in the world (Shah and Gupta, 2000). The impact of tourism is extremely varied. On one hand, it plays an important and certainly positive role in the socio-economic and political development in destination countries by, for instance, offering new employment opportunities. Also, in certain instances, it may contribute to a broader cultural understanding by creating awareness, respecting the diversity of cultures and ways of life (UNCSD \{United Nations Commission on Sustainable Development \}, 1999).

In another perspective, tourism contributes, to a greater degree than most activities, in the provision of a wide range of infrastructure services - airports, air navigation, roads, railheads and ports, as well as basic infrastructure services required by hotels, restaurants, shops, and recreation facilities (e.g. telecommunications and utilities). As such, it can be said that tourism is able to contribute to development which is economically, ecologically and socially sustainable, because it has less impact on natural resources and the environment than most other industries; it is based on enjoyment and appreciation of local culture, built heritage, and natural environment, as such that the industry has a direct and powerful motivation to protect these assets; it can play a positive part in increasing consumer commitment to sustainable development principles through its unparalleled consumer 
distribution channels; and it provides an economic incentive to conserve natural environments and habitats which might otherwise be allocated to more environmentally damaging land uses, thereby, helping to maintain bio-diversity (UNCSD \{United Nations Commission on Sustainable Development \}, 1999).

Various studies on accessibility of various facilities have pointed out that geographical distance is a force to reckon with (Caldwell, 1979; Bimal, 1991). Compounding the problem of geographical distance to these facilities are bad roads and poor access routes. The findings of various studies on adverse effects of geographical distance on access to necessary facilities are well documented (Page, 2002; Ridde, 2004; and Deogaonkar, 2004; Alo, 2005) and tourist sites are not left out in this bane of inaccessibility.

The level of accessibility in Nigerian towns and cities generally and in old Ondo State (the study area) in particular, whether for recreational, tourism or any other purposes need to be critically examined. Hence, this paper focused on the examination of the extent to which tourist sites in the study area are accessible.

\section{Literature Review}

Tourism is important in many countries, both developed and developing. It provides foreign exchange, employment, income and public and revenue. It has become an important sector and it potentially constitutes one of the fastest growing sectors. It has been declared as one of the top five sources of foreign currency for 83 percent of developing countries. The contribution of tourism receipts to total revenues in these countries is within the range of 80 and 20 percent (Benavides, 2001). During 1980 1987, for example, international tourist receipts grew by 45 percent or six times faster than exports in general (Bird, 1992).

According to UNCSD (1999), travel and tourism is the world's largest industry and creator of jobs across national and regional economies. WTTC/WEFA research shows that in 2000, travel and tourism will generate, directly and indirectly $11.7 \%$ of GDP and nearly 200 million jobs in the world-wide economy. These figures are forecasted to total $11.7 \%$ and 255 million respectively in 2010. Jobs generated by travel and tourism are spread across the economy - in retail, construction, manufacturing and telecommunications, as well as directly in travel and tourism companies. These jobs employ a large proportion of women, minorities and young people; are predominantly in small and medium sized companies; and offer good training and transferability. Tourism can also be one of the most effective drivers for the development of regional economies. These patterns apply to both developed and emerging economies.

In developing countries of Asia, Latin America and Africa, it is said that net foreign exchange earning has been significantly improved through the contribution of tourism (Sinclair, 1998; Shah and Gupta, 2000). A study by World Tourism Organisation (1998) indicated that it was common in "tourist countries" to get between $10-25$ percent of their fiscal revenues from tourism with the possibility that the proportion may go up to 50 percent for smaller and specialized tourist countries such as Bahamas. All these benefits accruable from the tourism indicate that accessibility to them is imperative. This is in order to save travel time and cost and also to ensure comfortability and satisfaction in the patronage of the tourist sites.

Some factors have been found to influence the patronage of social facilities in space. Some of these factors include cost, distance, social discrimination and accessibility (Nash, 1975 and Lewis, 1977). Prominent scholars like Mitchell and Town (1977) and Pooler (1995) have shown that two important factors influence the pattern of patronage of facilities, tourist sites inclusive. The two factors according to them are accessibility and time spent in reaching a particular facility or location in space.

Accessibility is a general term used to describe the degree to which a product (device, service or environment) is accessible by as many people as possible. Accessibility can be viewed as the "ability to access" the functionality, and possible benefit, of some system or entity. Accessibility is also used to focus on people with disabilities and their right of access to entities, often through use of assistive technology (Wikipedia encyclopaedia, 2009). It can be seen as ease and convenience with which a property can be entered by customers, tenants, and other users, particularly related to access via automobile. This ease of approach to one location from other locations may be measured in terms of 
the distance travelled, the cost of travel, or the time taken.

The importance of accessibility is rooted in the immense contribution it can have on socio-economic development. According to International Federation of Arts Councils and Culture Agencies (IFACCA) (2008), both tangible and intangible tourist sites can play a role in the development of local communities. Therefore, working at the preservation of the tourist sites contributes to strengthening a common sense of identity within a community. Thus, heritage as a common past is a source of the community identity. Through the recognition of the past, their preservation helps in the preparation for the future.

It is further stressed that the impact of heritage on local communities is not only immaterial: it can become very concrete as soon as local actors are involved in the preservation and promotion processes. Tourist sites, when well managed, can become a tool to share experiences, exchange know-how and to integrate local communities into international networks. Invariably, when it is linked to tourism, heritage can also become a direct source of income both at the individual and corporate levels (IFACCA, 2008).

Affirming the importance of accessibility, Onibokun (1973) and Nadar (1979) pointed out that the reason why people choose to travel in space is to obtain an opportunity, which is available at a location different from the point of origin of the tripmaker. Accessibility, a very crucial factor that influence patronage of tourist sites relates to the ease of overcoming some forms of frictions in terms of physical distance, time costs, monetary and inconvenience costs or a combination of these.

According to Morril (1996), in rural areas, access to economic activities is determined with a framework of elements of accessibility. It is probably as a result of this that Ikporukpo (2002) conceptualized accessibility in terms of the ability to get to a place quickly and cheaply and the availability and affordability of a utility. Again, some scholars have established a strong link between accessibility and distance to which people travel to make use of facilities (Moseley, 1979 and Peterson, 1980). In this case, distance may be considered in various perspectives such as physical distance, monetary distance and time distance.

In confirmation of the importance of distance to social facilities, Ogunjumo et al
(2005) posits that the distance of public healthcare facilities from patients' residence also played an important role in their patronage pattern. According to Edwards (1947), Chislom (1957) and Babadoye and Fadamiro (2003), distance as a factor militates against the length of travel. To them, the volume of trips to a particular location, say a tourist site, decreases as the distance increases. This view was also upheld by Omiunu and Onokerhoraye (1995) in their transport study of Benin City. They observed that more people travel shorter distances in their bid to make use of a facility or obtain a service at a particular location while few people travel further because of the incidence of cost.

The work of Anusionwu (1980) also exemplifies the individual patronage pattern of social facilities in space. His work was based on the patronage of primary schools in Nigeria. He noticed that the level of patronage of these schools by students decreases as the distance increases. Olanrewaju (1989) also noted the role of distance in spatial interaction in his work on central place theory in relation to the distribution of social amenities in local government areas. He observed that people are not usually disposed favourably to using facilities located in remote places as those located nearest to their $r$ esidences. Thus, he was of the opinion that effective accessibility to social facilities in space will enhance the extent to which people patronize them.

Morenikeji (2000) affirmed that there was a correlation between the pattern of spatial interaction between Local Government towns and their adjoining settlements. He revealed that there was an inverse relationship between distance and length of travel in his study. He further observed that spatial interaction is mostly predominant between each Local Government Area Headquarters and their adjoining settlements located nearby than those settlements that are far away from such Local Government Area headquarters. He concluded that a strong negative relationship exists between those distant settlements and their various local government area headquarters. All the scholars agreed that accessibility to the location of social facilities will be better enhanced the shorter the distance between patrons residence.

\section{Study Area}

The study covers the old Ondo State of Nigeria comprising the present Ekiti and Ondo states, which lies between longitudes $4^{0} 30^{1}$ and 
$6^{0} 00^{1}$ East of the Greenwich Meridian and latitudes $5^{0} 45^{1}$ and $8^{0} 15^{1}$ North of the Equator. It has an area of land of about 20,959 square kilometers. It is bounded in the North by Kwara and Kogi States (fig.2.); in the east by Edo and Delta States; in the West by Osun, Oyo and Ogun States; in the South by the Atlantic Ocean. The entire study area is situated within the tropics of Cancer.

The people of the study area comprise mainly the Yorubas who belong to a major tribe in Nigeria. The Yoruba people include those inhabiting Ekiti, Akure, Akoko and Ondo towns. The minority are the Ilaje and Ijaw who are found in the coastal area of these states. These people, as common to other Yorubas, have history, traditions and religion that are manifested in the presence of tourist sites dotted around the area. The population figure of the study area, based on the 1991 census put the figure at $3,884,465$. The latest census of 2006 in Nigeria put the population of the area at 5,825, 236

Physically, the old Ondo State is composed of low lands and rugged hills with granite outcrops in some places. Generally, the land rises from the coastal part of Ilaje and Ese -Odo areas in the south to the rugged hills towards the northern part, these include Idanre hills, Akoko hills and Ekiti hills. The rivers which traverse the study area include Ogbese, Osse, Owena, Oluwa, Oni and Ala to mention just a few. The climate of the area is tropical with two distinct seasons, the rainy season (April-October) and dry season (NovemberMarch). The presence hills and rivers in the study area will help support the need to study the factors that influence their patronage.

\section{Methodology}

Both primary and secondary data were used for this study. Primary data were collected through field surveys. This involved administration of questionnaires that sought information from patrons of tourist sites, where the tourist sites were found. An inventory of the study area revealed more than 30 tourist sites which formed the sample frame. Only 12 of these were selected to form the sample size due to their prominence and recognition by the old Ondo State Government in 1992 (see Table $1)$.

Purposive incidental sampling technique was used to select a total of 358 respondents. The questionnaire was designed to collect data on such variables as age, sex, marital status, education, place of origin, occupation, family size, car ownership, religious affiliation, purpose of patronage, mode of patronage, frequency of patronage, duration or hours of patronage and quality of services given at these sites.

Relevant information was collected from published materials in Government Organizations and Ministries. These included the National Commission for Museums and Monuments in Akure, the Deji's Palace; Ondo State Cultural Centre, National Population Commission at Akure and Department of Research and Statistics of the Ministry of Finance, Economic Planning and Budget Bureau of Ondo State. Other necessary information were collected from textbooks, official documents, journals and newspapers, to further strengthen the research.

\section{Results and Discussion}

This section discusses the results of the analysis. It talks about the level of accessibility of the tourist sites, distance of patrons' residence to tourist sites, reasons for patronage of tourist sites and volume and pattern of patronage of tourist sites.

\section{Level of Accessibility of Tourist} Sites

Table 2 shows the relative assessment of the patrons on the level of accessibility of the sampled tourist sites. These were depicted in the table using variables such as "very accessible", "poorly accessible", and "not accessible". The table shows the perceptions of respondents of these tourist sites. In their own view, 39.3\% respondents say that the tourist sites were very accessible while $22.6 \%, 19.7 \%$ and $18.4 \%$ of the total number of patrons indicated that they were accessible, poorly accessible and not accessible respectively. It should be noted that tourist sites that were found in rural towns like Iho-Eleru of Isarun $(1.7 \%)$, Ayetoro $(1.1 \%)$ and Iponle-Iloro in $(0.6 \%)$ were rated not very accessible. The reason for the low level of accessibility at the Holy Apostles Community at Ayetoro is understandable. This is because it is located on the sea and could only be accessible by boats.

\section{Distance of Patrons' Residence to Tourist sites}

It is generally believed that few people will be willing to patronize a particular facility or service as the distance from it increases. This situation is evident in Table 3. Apart from 
this, distance is an important factor which influences not only patronage of tourist sites but also other social infrastructural facilities such as shopping centres, schools, health centres and postal agencies, among others. It must be pointed out again, that there is a limit to the distance patrons will be prepared to travel on the grounds of patronizing a particular tourist site especially when such a tourist site is not a major type that command maximum enjoyment.

Table 3 shows the distance covered by patrons of each tourist site. It reveals that $24.9 \%$ of the patrons patronized tourist sites that are not more than 5 kilometres away from their residences. Next to this group were those patrons $(20.9 \%)$ that travelled within 5-9 kilometres. It could be noted from the table that as distance covered increases the volume of patronage decreases.

\section{Reasons for Patronage of Tourist Sites}

There were different reasons given by patrons for their patronage of tourist sites. This is because the patrons were of different socioeconomic, cultural, religious and educational backgrounds. The result of this is the selection of varied tourist sites that satisfy their reasons for embarking on such journeys. For instance, patrons that have high economic status may prefer to travel long distance, not minding the cost, in order to enjoy what a tourist site has to offer.

Table 4 shows some of the reasons for making the choice of which tourist site to visit. The factors considered include proximity, preference, cost and religion. It should be stressed that $31 \%$ of the respondents adopted cost minimization as factor for the choice of tourist sites they visited. Others, $30.4 \%, 19.8 \%$ and $19.7 \%$ indicated preference, proximity and religion respectively. It appears that cost of patronage of tourist sites in the study area occupies the central place in the minds of patrons owing to the dwindling economic situation of the nation.

\section{Conclusion}

This paper has pointed out that accessibility is a major issue in the patronage of tourist sites. The more tourist sites are opened up by roads, the more they become accessible to various patrons whose movement create unique pattern on a spatial landscape. Good accessibility would reduce cost of patronage of tourist sites and would enable patrons to travel longer distance to patronize tourist sites that satisfy their recreational needs.

Apart from this, accessibility to tourist sites will boost the volume of patronage and consequently, the socio-economic developments of the host environment. It is against these backdrops that this paper calls on government at various levels and nongovernmental organisations to ensure a concerted effort in the improvement of access to tourist sites located in the rural areas as well as in the urban centres.

Local government councils in Ondo and Ekiti states should take inventory of all tourist sites in their localities and these should be published in their official gazettes either quarterly or annually so as to bring these tourist sites into limelight.

Moreover, governments of Ondo and Ekiti States should ensure that a reasonable amount of money is earmarked for the development of these sites in their annual budget. The rehabilitation of tourist sites should be thoroughly monitored by government operatives so as to stall their abandonment.

In the same vein, there could be collaboration between the government and the private sector to ensure public-private participation in boosting the image of these tourist sites. The government could help to create an enabling environment and to ensure the monitoring of their sustenance while the private sector sees to their financing and management. It is believed that this participation will contribute immensely towards better accessibility to and patronage of the tourist sites and ultimately enhance their contribution towards the development of local and national economy. 


\section{References}

Alo, Y. C. (2005): ‘Accessibility of Urban Poor to Health Facilities: A Case Study of Gbodo, Ile-Ife, Osun State'. An unpublished Independent Project, Department of Urban and Regional Planning, Obafemi Awolowo University, Ile-Ife, Nigeria.

Anusionwu, E.C. (1980) "The Determinant of Regional Distribution of Primary and Secondary Education in Nigeria". The Nigerian Journal of Economic And Social Sciences. Vol. 22, No. 1, pp. 3-22.

Babadoye, S.A. and Fadamiro, J. (2003) "Movement Pattern and Effective Accessibility for a Sustainable Built Environment: A Case Study of Akure, Nigeria", in Adekunle, V.; E. Okoko and S.A. Adeduntan (ed.) Proceedings of Workshop on Challenges of Environmental Sustainability in a Democratic Government. Akure: Federal University of Technology.

Benavides, D. (2001) Is the Socio-economic Sustainability of International Tourism

Assured under Hyper-competitive Conditions?

Available online at www.sommetstourisme.org

Bimal, K. P. (1991): 'Health Service Resource as a Determinant of Infant Death in Rural Bangladesh: An Empirical Review'. Social Science Medicine, Vol. 32, No. 1, pp. 43 - 49.

Caldwell, J. (1979): 'Education as a Factor in Mortality Decline: An Examination of Nigerian Data'. Population Studies Vol. 33, No. 3, pp. $396-413$.

Chislom, M. (1957) "Regional Variations in Road Transport Costs: Milk Collection from Farms in England and Wales". Farm Economics, Vol. 8, pp. 30-38.

Deogaonkar, Milind (2004): 'Socio-Economic Inequality and Its Effect on Health Care Delivery in India: Inequality and Health Care'. Electronic Journal of Sociology.

Edwards, F. K. (1947) "Cost Analysis in Transportation". Papers and Proceedings of the American Economic Association, pp. 441461.

IFACCA (2008) Preservation of Cultural Heritage and Local Community Development, According to International Federation of Arts Councils and Culture Agencies.

Available online http://www.ifacca.org/events/2008/05
Ikporukpo, C. O.(2002): Spatial Engineering and Accessibility. An Inaugural Lecture, University of Ibadan. Ibadan: Vantage Publishers Ltd.

Lewis, D. (1977) "Estimating the Influence of Public Transport on Road Traffic Levels

in Greater London", Journal of Transport Economic and Policy, Vol. II, No. 2.

Mitchell, C.G.B. and Town, S.W. (1977) Accessibility of Various Social Groups to Different Activities. TRRL, SR 258, Crowthorne, England.

Morenikeji, W. (2000) "Effects of Distance from Local Government Area Headquarters on the Development of Hinterland Settlements in Ondo State." The Nigerian Journal of Economic and Social Studies. Vol. 42, No. 8594.

Morril, R. (1996): "Spatial Engineering and Geographical Integrity.'Political Geography Vol 15 No. 1

Moseley, M.H. (1979) Accessibility: The Rural Challenge. Methuen and Co. Ltd., London

Nadar, G. (1979) "Socio-Economic Status and Consumer Behaviour", Urban Studies,

Vol. 6.

Nash, C. A. (1975) Economics of Public Transport. Longmans Inc. New York.

Netzer, D. (1997) "The Economic Implications of Heritage Conservation", Urban Age, Vol. 4; No. 4. Worked Bank Washington, D.C. USA.

Ogunjumo, Ajibade, Adewale Amusan and Olufemi Omisore (2005): Bivariate Analysis of Factors of Location of Public Health Care Facilities. Journal of Nigerian Institute of Town Planners. Vol xviii.

Okoko, E. (2000) Quantitative Techniques in Urban Analysis. Kraft Books Limited, Ibadan. Omiunu, E. G. and Onokerhoraye, A.G. (1995) Transport and the Nigerian SpaceEconomy. Benin City Series for Africa, Urban and Regional Planning, Benin City.

Olanrewaju, S.A. (1989) "Central Place

Theory as a Planning tool at the Local Government Level”. Nigeria Journal of Local Government Studies. Vol. 13, No.1. 
Onibokun, A. (1973) "Forces shaping the Physical Environment of Cities in the

Developing Countries: The case of Ibadan," Land Economics, Vol.49.

Onokerhoraye, A.G. (1986) An Outline of Human Geography. Department of

Geography and Regional Planning, University of Benin, Benin City.

Page, Alan (2002): 'Poor Housing and Mental Health in the United Kingdom: Changing

the Focus for Intervention' in Journal of Environmental Health Research, Vol. 1

No. 1, pp. $31-40$.

Peterson, E.O. (1980) Transportation in Cities. Pergamon Press. New York.

Pooler, J. A. (1995) "The Use of Spatial Separation in the Measurement of Transportation Accessibility". Transportation Research. No. A 29. pp. 421-427.

Ridde, Valery (2004): Health Financing and Access to Health Care for Women In Afghanistan: Evidence from an NGO Intervention. An evaluation funded by the European Union.
Shah, K. and Gupta, V, (2000) Tourism, the Poor and other Stakeholders: Asian Experience. London: ODI Fair Trade in Tourism Paper.

Sinclair, M. T. (1998) Tourism and Economic Development: A Survey. The Journal of Development Studies, Vol. 34, No 5 (June). Smith, H.W. (1975) Strategies of Social Research: The Methodological Imagination. Prentice-Hall Inc, Englewood Cliffs, New Jersey.

Social Exclusion Unit Report (2003): Office of the Deputy Prime Minister, Eland House, London. www.socialexclusion.gov.uk (UNCSD \{United Nations Commission on Sustainable Development\}, 1999) Global Importance of Tourism. Commission on Sustainable DevelopmentSeventh Session 1930 April 1999, New York

Wikipedia Encyclopedia (2009) An online Encyclopedia available at http://en.wikipedia.org/accessibility.html WTO (1998) Compendium of Tourism Statistics 1993 - 1997, Nineteenth Edition. Madrid: World Tourism Organisation. 
Table 1: Tourist Sites in Ondo and Ekiti States

\begin{tabular}{|l|l|l|}
\hline S/N & Tourist site & Town \\
\hline 1 & Ikogosi Warm Spring & Ikogosi Ekiti \\
\hline 2 & Idanre Hills & Idanre \\
\hline 3. & Deji's Palace & Akure \\
\hline 4. & Oke Maria & Oka Akoko \\
\hline 5. & Olosunta Hills & Ikere Ekiti \\
\hline 6. & Owo Museum of Antiquities & Owo \\
\hline 7. & Fajuyi Memorial Park & Ado Ekiti \\
\hline 8. & Iponle-Iloro Water Falls & Iponle-Iloro \\
\hline 9. & Igbara-Oke Petroglyphs & Igbara-Oke \\
\hline 10. & Ebomi Lake & Ipesi Akoko \\
\hline 11. & Iho-Eleru & Isarun \\
\hline 12. & Holy Apostles Community & Aiyetoro \\
\hline
\end{tabular}

Source: Ondo State (1992), Facts and Figures about Ondo State, Department of Research and Statistics, Governor Office, Akure.

Table 2: Level of Accessibility of Tourist Sites

\begin{tabular}{|c|c|c|c|c|c|c|c|c|c|c|c|}
\hline \multirow[b]{3}{*}{$\mathbf{S} / \mathbf{N}$} & \multirow[b]{3}{*}{$\begin{array}{l}\text { Tourist } \\
\text { Sites }\end{array}$} & \multicolumn{10}{|c|}{ Level of Accessibility } \\
\hline & & \multicolumn{2}{|c|}{ Very Accessible } & \multicolumn{2}{|c|}{ Accessible } & \multicolumn{2}{|c|}{$\begin{array}{c}\text { Poorly } \\
\text { Accessible }\end{array}$} & \multicolumn{2}{|c|}{ Not Accessible } & \multicolumn{2}{|c|}{ Total } \\
\hline & & $\begin{array}{l}\text { No. of } \\
\text { responde } \\
\text { nts }\end{array}$ & $\%$ & $\begin{array}{l}\text { No of } \\
\text { respond } \\
\text { ents }\end{array}$ & $\%$ & $\begin{array}{l}\text { No of } \\
\text { respond } \\
\text { ents }\end{array}$ & $\%$ & $\begin{array}{l}\text { No of } \\
\text { respond } \\
\text { ents }\end{array}$ & $\%$ & $\begin{array}{c}\text { No of } \\
\text { respond } \\
\text { ents }\end{array}$ & $\%$ \\
\hline 1 & $\begin{array}{l}\text { Deji's } \\
\text { Palace }\end{array}$ & 10 & 2.8 & 12 & 3.4 & - & - & 16 & 4.5 & 38 & 10.6 \\
\hline 2 & Ebomi Lake & 8 & 2.2 & 3 & 0.8 & - & - & 3 & 0.8 & 14 & 3.9 \\
\hline 3 & $\begin{array}{l}\text { Fajuyi } \\
\text { Memorial } \\
\text { Park }\end{array}$ & 14 & 3.9 & 9 & 2.5 & 2 & 0.6 & 1 & 0.3 & 26 & 7.3 \\
\hline 4 & $\begin{array}{l}\text { Holy } \\
\text { Apostles } \\
\text { Community }\end{array}$ & 4 & 1.1 & 8 & 2.2 & 8 & 2.2 & 4 & 1.1 & 24 & 6.7 \\
\hline 5 & Idanre Hills & 32 & 8.9 & - & - & 10 & 2.8 & 13 & 3.6 & 55 & 15.4 \\
\hline 6 & $\begin{array}{l}\text { Igbara-Oke } \\
\text { Petroglyphs }\end{array}$ & 9 & 2.5 & 6 & 1.7 & 1 & 0.3 & 7 & 2.0 & 23 & 6.4 \\
\hline 7 & $\begin{array}{l}\text { Iho-Eleru } \\
\text { Isarun }\end{array}$ & 2 & 0.6 & 2 & 0.6 & 9 & 2.5 & 6 & 1.7 & 19 & 5.3 \\
\hline 8 & $\begin{array}{l}\text { Ikogosi } \\
\text { Warm } \\
\text { Spring }\end{array}$ & 26 & 7.3 & 21 & 5.9 & 12 & 3.4 & 2 & 0.6 & 61 & 17.0 \\
\hline 9 & $\begin{array}{l}\text { Iponle Iloro } \\
\text { Water Falls }\end{array}$ & 2 & 0.6 & 6 & 1.7 & 5 & 1.4 & 2 & 0.6 & 15 & 4.2 \\
\hline 10 & Oka Hills & 11 & 3.1 & 12 & 3.4 & 2 & 0.6 & 6 & 1.7 & 31 & 8.7 \\
\hline 11 & $\begin{array}{l}\text { Olosunta } \\
\text { Hills }\end{array}$ & 18 & 5.0 & - & - & 6 & 1.7 & 5 & 1.4 & 29 & 8.1 \\
\hline 12 & $\begin{array}{l}\text { Owo } \\
\text { Museum }\end{array}$ & 7 & 2.0 & 2 & 0.6 & 13 & 3.6 & 1 & 0.3 & 23 & 6.4 \\
\hline & Total & 143.0 & 40.0 & 81.0 & 22.6 & 68.0 & 19.1 & 66.0 & 18.6 & 35.8 & 100.0 \\
\hline
\end{tabular}


Table 3: Distance of Patrons' Residence to Tourist Sites

\begin{tabular}{|c|c|c|c|c|c|c|c|c|c|c|c|c|c|c|c|}
\hline \multirow{3}{*}{$\mathbf{S} / \mathbf{N}$} & \multirow{3}{*}{$\begin{array}{l}\text { Tourist } \\
\text { Sites }\end{array}$} & \multicolumn{14}{|c|}{ Distance of Patrons' residence } \\
\hline & & \multicolumn{2}{|c|}{$\begin{array}{l}\text { Less than } \\
5 \mathrm{~km}\end{array}$} & \multicolumn{2}{|c|}{$5-9 \mathrm{~km}$} & \multicolumn{2}{|c|}{$10-14 \mathrm{~km}$} & \multicolumn{2}{|c|}{$15-19 \mathrm{~km}$} & \multicolumn{2}{|c|}{$20-24 \mathrm{~km}$} & \multicolumn{2}{|c|}{$\begin{array}{l}\text { Above } \\
24 \mathrm{~km}\end{array}$} & \multicolumn{2}{|c|}{ Total } \\
\hline & & No & $\%$ & No & $\%$ & No & $\%$ & No & $\%$ & No & $\%$ & No & $\%$ & No & $\%$ \\
\hline 1 & Deji's Palace & 15 & 4.2 & 3 & 0.8 & 4 & 1.1 & 4 & 1.1 & 5 & 1.4 & 7 & 2.0 & 38 & 10.6 \\
\hline 2 & Ebomi Lake & 6 & 1.7 & 3 & 0.8 & - & - & - & - & - & - & 5 & 1.4 & 14 & 3.9 \\
\hline 3 & $\begin{array}{l}\text { Fajuyi } \\
\text { Memorial } \\
\text { Park }\end{array}$ & 5 & 1.4 & 10 & 2.8 & 1 & 0.3 & 2 & 0.6 & 8 & 2.2 & - & - & 26 & 7.3 \\
\hline 4 & $\begin{array}{l}\text { Holy } \\
\text { Apostolic } \\
\text { Community }\end{array}$ & - & - & 8 & 2.2 & 8 & 2.2 & 8 & 2.2 & - & - & - & - & 24 & 6.7 \\
\hline 5 & Idanre Hills & 22 & 6.1 & - & - & 16 & 4.5 & 10 & 2.8 & 7 & 2.0 & - & - & 55 & 15.4 \\
\hline 6 & $\begin{array}{l}\text { Igbara-Oke } \\
\text { Petrolyphs }\end{array}$ & 5 & 1.4 & 4 & 1.1 & 4 & 1.1 & 5 & 1.4 & 4 & 1.1 & 1 & 0.3 & 23 & 6.4 \\
\hline 7 & Iho-Eleru & 5 & 1.4 & 5 & 1.4 & 3 & 0.8 & 3 & 0.8 & - & - & 3 & 0.8 & 19 & 5.3 \\
\hline 8 & $\begin{array}{l}\text { Ikogosi } \\
\text { Warm Spring }\end{array}$ & 14 & 3.9 & 23 & 6.4 & 3 & 0.8 & 10 & 2.8 & 11 & 3.1 & - & - & 61 & 17.0 \\
\hline 9 & $\begin{array}{l}\text { Iponle-Iloro } \\
\text { Water Falls }\end{array}$ & - & - & 4 & 1.1 & 6 & 1.7 & 5 & 1.4 & - & - & - & - & 15 & 4.2 \\
\hline 10 & Oka Hills & 5 & 1.4 & 8 & 2.2 & 7 & 2.0 & 6 & 1.7 & 5 & 1.4 & - & - & 31 & 8.7 \\
\hline 11 & $\begin{array}{l}\text { Olosunta } \\
\text { Hills }\end{array}$ & 6 & 1.7 & - & - & 12 & 3.4 & 6 & 1.7 & 5 & 1.4 & - & - & 29 & 8.1 \\
\hline 12 & $\begin{array}{l}\text { Owo } \\
\text { Museum }\end{array}$ & 6 & 1.7 & 7 & 2.0 & 2 & 0.6 & 3 & 0.8 & 1 & 0.3 & 4 & 1.1 & 23 & 6.4 \\
\hline & Total & 89 & 24.9 & 75 & 20.9 & 66 & 18.4 & 62 & 17.3 & 46 & 12.8 & 20 & 4.6 & 358 & 100.0 \\
\hline
\end{tabular}

Table 4: Reasons for patronage of Tourist Sites

\begin{tabular}{|c|c|c|c|c|c|c|c|c|c|c|c|}
\hline \multirow[b]{3}{*}{$\mathbf{S} / \mathbf{N}$} & \multirow[b]{3}{*}{ Tourist Sites } & \multicolumn{10}{|c|}{ Reason for making choice on the Tourist Site to visit } \\
\hline & & \multicolumn{2}{|c|}{$\begin{array}{l}\text { Proximity } \\
\text { factor }\end{array}$} & \multicolumn{2}{|c|}{$\begin{array}{l}\text { Preference } \\
\text { Factor }\end{array}$} & \multicolumn{2}{|c|}{$\begin{array}{l}\text { Cost } \\
\text { Factor }\end{array}$} & \multicolumn{2}{|c|}{$\begin{array}{l}\text { Religious } \\
\text { Factor }\end{array}$} & \multicolumn{2}{|c|}{ Total } \\
\hline & & No. & $\%$ & No & $\%$ & No & $\%$ & No & $\%$ & No & $\%$ \\
\hline 1 & $\begin{array}{l}\text { Deji's } \\
\text { Palace }\end{array}$ & 4 & 1.1 & 12 & 3.4 & - & - & 2.2 & 6.1 & 38 & 10.6 \\
\hline 2 & $\begin{array}{l}\text { Ebomi } \\
\text { Lake }\end{array}$ & 2 & 0.6 & 12 & 3.4 & - & - & - & - & 14 & 3.9 \\
\hline 3 & $\begin{array}{l}\text { Fajuyi Memorial } \\
\text { Park }\end{array}$ & 1 & 0.3 & 11 & 3.1 & 6 & 1.7 & 8 & 2.2 & 26 & 7.3 \\
\hline 4 & $\begin{array}{l}\text { HolyApostles } \\
\text { Community }\end{array}$ & 4 & 1.1 & 8 & 2.2 & 12 & 3.4 & - & - & 24 & 6.7 \\
\hline 5 & $\begin{array}{l}\text { Igbara-Oke } \\
\text { Petroglyphs }\end{array}$ & 8 & 2.2 & 3 & 0.8 & 8 & 2.2 & 4 & 11 & 23 & 6.4 \\
\hline 6 & Idanre Hills & 12 & 3.4 & 16 & 4.5 & 22 & 6.1 & 5 & 1.4 & 55 & 15.4 \\
\hline 7 & Iho-Eleru Isarun & 6 & 1.7 & 2 & 0.2 & 7 & 2.0 & 4 & 1.1 & 19 & 5.3 \\
\hline 8 & $\begin{array}{l}\text { Ikogosi Warm } \\
\text { Spring }\end{array}$ & 11 & 3.1 & 24 & 6.7 & 9 & 2.5 & 17 & 4.7 & 61 & 17 \\
\hline 9 & $\begin{array}{l}\text { Iponle-Iloro Water } \\
\text { Falls }\end{array}$ & 2 & 0.6 & 5 & 1.4 & 8 & 2.2 & - & - & 15 & 4.2 \\
\hline 10 & Oka Hills & 11 & 3.1 & 6 & 1.7 & 9 & 2.5 & 5 & 1.4 & 31 & 8.7 \\
\hline 11 & $\begin{array}{l}\text { Olosunta } \\
\text { Hills }\end{array}$ & - & - & 6 & 1.7 & 23 & 6.4 & - & - & 29 & 8.1 \\
\hline \multirow[t]{2}{*}{12} & $\begin{array}{l}\text { Owo } \\
\text { Museum }\end{array}$ & 10 & 2.8 & 4 & 1.1 & 7 & 2.0 & 2 & 0.6 & 23 & 6.4 \\
\hline & Total & 71 & 19.8 & 109 & 30.4 & 111 & 31.0 & 67 & 18.7 & 358 & 100.0 \\
\hline
\end{tabular}

Source: Authors' Fieldwork, 2006 